\title{
Sistem Informasi Manajemen Mutu Produk Di PT Deltomed Laboratories Wonogiri
}

\author{
Fajar Dwi Septian ${ }^{\mathrm{a}, 1}$, Donna Setiawati ${ }^{\mathrm{b}, 2^{*}}$, Ari Pantjarani ${ }^{\mathrm{b}, 3}$ (11pt) \\ ${ }^{a}$ Fakultas Ilmu Komputer Universitas Boyolali, Boyolali. Jl. Pandanaran No.405, Boyolali 57314, Indonesia \\ ${ }^{\mathrm{b}}$ AMIK Harapan Bangsa Surakarta, Jl. Ir. Sutami No.46, Sekarpace Surakarta 57126, Indonesia \\ ${ }^{1}$ dwfajar@gmail.com *; ${ }^{2}$ donna.setiawati@gmail.com; ${ }^{3}$ pantjarani@gmail.com \\ * Koresponsendi penulis
}

ARTICLE INFO

Article history

Menerima

Revisi

Diterima

Kata Kunci

PMP

Information

System

Management

Quality

\section{ABSTRACT (10PT)}

This research is entitled Sistem Informasi Manajemen Mutu Produk Di PT Deltomed Laboratories Wonogiri. This study aims to create a product quality management information system at PT Deltomed Laboratories, facilitate information management \& product quality administration, and create efficiency and effectiveness in the process of product quality management for the better. The system development method used in this study is Waterfall where the process starts from Communication, Planning, Modeling, Construction and Deployment. For system design tools using UML diagrams with the Visual Basic programming language and MySQL Database. The results achieved are a product quality management information system that facilitates information management \& product quality administration, as well as creating work efficiency and effectiveness in the process of product quality management for the better.

\section{Pendahuluan}

Teknologi informasi saat ini berkembang begitu pesat. Karena pentingnya penggunaan teknologi informasi merupakan suatu kebutuhan bagi sebuah instansi untuk mencapai efisiensi dan efektifitas kerja maka saat ini, proses penyampaian informasi yang dimiliki oleh PT Deltomed Laboratories telah terkomputerisasi. Namun, bukan berarti semua proses informasi telah terkomputerisasi. Masih beberapa proses yang dilakukan secara manual. Satu dari beberapa proses tersebut antara lain manajemen kajian mutu produk yang di produksi oleh PT Deltomed Laboratories.

Dalam manajemen kajian mutu produk saat ini PT Deltomed Laboratories masih menggunakan proses semi manual (dengan Excel). Dalam hal ini dari team internal sering mangalami kesulitan untuk mencari informasi dengan cepat, berbagi informasi dengan department lain \& harus melakukan double job dari setiap input kajian mutu produk yang direkap setiap harinya. Karena disamping melakukan input kajian mutu, department terkait juga masih harus menyediakan report dalam format baku \& juga dalam format grafik sesuai dengan standart format report kajian dari badan POM. Untuk itu, maka diperlukan adanya sebuah sistem informasi manajemen kajian mutu produk di PT Deltomed Laboratories, dengan harapan semoga dalam operasional, efisisiensi, dan efektivitas kerja untuk kedepanya akan menjadi lebih baik

\section{Tinjauan Pustaka}

\subsection{Manajemen Mutu}

Manajemen mutu adalah sebuah sistem manajemen untuk mengawasi semua kegiatan dan tugas dalam suatu organisasi untuk memastikan bahwa produk dan layanan yang ditawarkan, serta sarana yang digunakan untuk mencapainya bersifat konsisten. Hal ini diperlukan untuk mencapai dan mempertahankan tingkat mutu yang diinginkan dalam organisasi. Termasuk di dalamnya penentuan kebijakan mutu, menciptakan dan menerapkan perencanaan dan jaminan kualitas, dan 
kontrol kualitas serta peningkatan kualitas. Pada proses manajemen mutu melibatkan kumpulan pedoman yang sudah dikembangkan oleh tim untuk memastikan bahwa produk dan layanan yang dihasilkan memiliki standar yang tepat atau sesuai dengan tujuan. [1]

Aktivitas pada proses manajemen mutu dimulai ketika organisasi menetapkan target kualitas yang harus dipenuhi dan yang disepakati dengan pelanggan. Organisasi kemudian mendefinisikan bagaimana target akan diukur. Kemudian mengambil tindakan yang diperlukan untuk mengukur kualitas. Selanjutnya mengidentifikasi masalah kualitas yang muncul dan memulai perbaikan. Langkah terakhir melibatkan pelaporan tingkat keseluruhan kualitas yang dicapai. Proses ini memastikan bahwa kualitas dan desain produk serta layanan yang dihasilkan oleh tim sesuai dengan harapan pelanggan. Metode peningkatan kualitas terdiri dari tiga komponen:, yaitu peningkatan kualitas produk, peningkatan kualitas proses, dan peningkatan kualitas berbasis orang.[2]

Jadi manajemen mutu merupakan gabungan dari semua fungsi manajemen yang dibangun berdasarkan konsep kualitas yang berorientasi pada kepuasan pelanggan.[3]

\subsection{Sistem Informasi}

Sistem informasi yaitu suatu sistem yang menyediakan informasi untuk manajemen dalam mengambil keputusan dan juga untuk menjalankan operasional perusahaan, di mana sistem tersebut merupakan kombinasi dari orang-orang, teknologi informasi dan prosedur-prosedur yang tergorganisasi. Biasanya suatu perusahan atau badan usaha menyediakan semacam informasi yang berguna bagi manajemen.[4]

\subsection{Database}

Database adalah kumpulan informasi informasi yang disimpan di dalam komputer secara sistematik sehingga dapat diperiksa menggunakan suatu program komputer untuk memperoleh informasi dari basis data tersebut. Database pengertian umumnya adalah sistem penyimpanan data imana data yang sudah banyak diinput disimpan dalam satu sistem penyimpanan. Software atau Perangkat lunak yang digunakan untuk mengelola dan memanggil kueri (query) basis data atau database disebut dengan sistem manajemen basis data (database management system, / DBMS).[5]

Sistem basis data dipelajari dalam ilmu informasi. Proses memasukkan (Input) dan mengambil data dari media penyimpanan data memerlukan perangkat lunak yang disebut dengan sistem manajemen basis data (database management system / DBMS). DBMS atau Database management system merupakan suatu sistem perangkat lunak (software) yang memungkinkan pengguna basis data (database user) untuk memelihara, mengontrol dan mengakses data secara praktis dan efisien.[5]

\subsection{MySQL}

MySQL adalah sebuah software atau perangkat lunak system manajemen berbasis data SQL atau juga multi user dan DBMD Multithread. Pada dasarnya, MySQL ini sebenarnya adalah turunan yang berasal dari salah satu konsep utama dalam database yang memang telah ada sebelumnya yaitu SQL atau Structured Query Language. Konsep ini digunakan untuk seleksi atau pemilihan dan pemasukan data dimana hal ini memungkinkan pengerjaan operasi data yang otomatis lebih mudah. MySQL sendiri diciptakan pada tahun 1979 oleh seorang programmer komputer yang berasal dari Swedia bernama Michael "Monty" Widenius. [6]

Keistimewaan dari software ini diantaranya adalah portabilitas yang berarti MySQL bisa berjalan stabil di system operasi apapun seperti Linux, Windows dan lain sebagainya. Kemudian MySQL juga multi-user sehingga bisa digunakan secara bersamaan oleh beberapa pengguna. Selain itu, MySQL juga memiliki tipe data beragam, beberapa keamanan, kecepatan yang tinggi, dan penanganan basis data yang bisa dilakukan dalam skala yang besar.[6]

\subsection{Pengembangan Software Model Waterfall}

Menurut Pressman (2015:42), model Waterfall adalah model klasik yang bersifat sistematis, berurutan dalam membangun sebuah software. Nama model ini sebenarnya adalah "Linear 
Sequential Model". Model ini termasuk ke dalam model generik pada rekayasa perangkat lunak dan pertama kali model Waterfall ini diperkenalkan oleh Winston Royce pada tahun 1970. Meskipun sering dianggap kuno, tetapi model Waterfall ini merupakan model yang paling banyak dipakai dalam Software Engineering (SE). Model Waterfall ini melakukan pendekatan secara sistematis dan berurutan. Model ini disebut dengan model Waterfall karena tahap demi tahap yang dilalui harus menunggu selesainya tahap sebelumnya dan berjalan berurutan.[7]

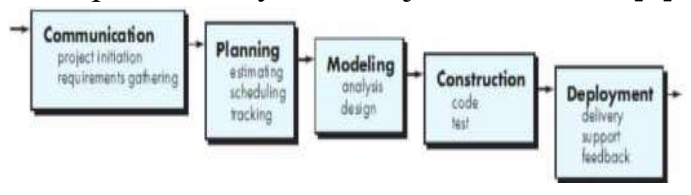

Gambar 2.1 Fase - Fase dalam Model Waterfall

Beberapa ahli membagi proses-proses pengembangan sistem ke dalam sejumlah urutan yang berbeda-beda. Tetapi semuanya akan mengacu pada proses-proses standar berikut: Analisis, Desain, Implementasi, Pemeliharaan. Pada perkembangannya,proses-proses standar tadi di tuangkan dalam satu metode yang di kenal dengan nama Systems Development Lifle Cycle (SDLC) yang merupakan metodologi umum dalam pengembangan sistem yang menandai kemajuan usaha analisis dan desain. SDLC meliputi fase-fase sebagai berikut: Identifikasi dan seleksi proyek, Inisiasi dan perencangan proyek, Analisis, Desain, Implementasi, Pemeliharaan, Identifikasi dan Seleksi Proyek.[8]

\subsection{Unified Modeling Languange (UML)}

Pengertian UML (Unified Modelling Language) Adalah bahasa grafis untuk mendokumentasikan, menspesifikasikan, dan membangun sistem perangkat lunak. Dengan UML dapat dibuat model untuk semua jenis aplikasi piranti lunak, dapat berjalan pada piranti keras, sistem operasi dan jaringan apapun, serta ditulis dalam bahasa pemrograman apapun. UML mendefinisikan notasi dan syntax/semantic.[9]

\subsection{Pengertian Efisiensi \& Efektivitas}

Menurut Ravianto dalam Masruri (2014), pengertian efektifitas adalah seberapa baik pekerjaan yang dilakukan, sejauh mana orang menghasilkan keluaran sesuai dengan yang diharapkan. Ini berarti bahwa apabila suatu pekerjaan dapat diselesaikan dengan perencanaan, baik dalam waktu, biaya mau pun mutunya, maka dapat dikatakan efektif.

Efisiensi adalah ukuran tingkat penggunaan sumber daya dalam suatu proses. Semakin hemat/sedikit penggunaan sumber daya, maka prosesnya dikatakan semakin efisien. Proses yang efisien ditandai dengan perbaikan proses sehingga menjadi lebih murah dan lebih cepat.[10]

\section{8. СРОТВ}

Cara Pembuatan Obat Tradisional yang Baik yang selanjutnya disingkat CPOTB adalah seluruh aspek kegiatan pembuatan obat tradisional yang bertujuan untuk menjamin agar produk yang dihasilkan senantiasa memenuhi persyaratan mutu yang ditetapkan sesuai dengan tujuan penggunaannya.[11]

CPOTB yang terbaru adalah tahun 2011 dan merupakan edisi ke tiga. Edisi sebelumnya adalah CPOTB tahun 1991 dan 2005. CРOTB merupakan bagian dari sistem penjaminan mutu. (Kepala BPOM, 2012). CPOTB adalah bagian dari Pemastian Mutu yang memastikan bahwa obat dibuat dan dikendalikan secara konsisten untuk mencapai standar mutu yang sesuai dengan tujuan penggunaan dan dipersyaratkan dalam izin edar dan spesifikasi produk.[12]

\subsection{Penelitian Terdahulu}

1. Della Novie Roseta (2017) Della Novie Roseta Melakukan penelitian tentang Manajemen Mutu Industri Farmasi. Industri farmasi memiliki persyaratan khusus dalam manajemen mutu 
produknya yaitu harus memenuhi aturan Cara Pembuatan Obat yang Baik (CPOTB ). Untuk mencapai tujuan mutu secara konsisten dan dapat diandalkan, diperlukan sistem Pemastian Mutu yang didesain secara menyeluruh dan diterapkan secara benar serta menginkorporasi Cara Pembuatan Obat yang Baik termasuk Pengawasan Mutu dan Manajemen Risiko Mutu. Penerapan sistem manajemen mutu ini bertujuan untuk memastikan bahwa sifat maupun mutu obat yang dihasilkan senantiasa memenuhi persyaratan mutu yang telah ditentukan dan sesuai dengan tujuan penggunaannya.[13]

2. Isnam Junais, Nurdin Brasit Dan Rindam Latief (2018). Isnam Junais, Nurdin Brasit Dan Rindam Latief melakukan penelitian tentang Kajian Strategi Pengawasan Dan Pengendalian Mutu Produk Ebi Furay PT. Bogatama Marinusa yang bertujuan untuk mengetahui implementasi sistem pengawasan dan pengendalian mutu produk pada PT. Bogatama Marinusa, penerapan standar mutu terhadap implementasi pengawasan dan pengendalian mutu produk pada PT. Bogatama Marinusa, mengidentifikasi faktor-faktor yang menyebabkan terjadinya produk cacat pada PT. Bogatama Marinusa, merumuskan startegi yang diperlukan untuk melakukan koreksi terhadap pengawasan dan pengendalian mutu produk PT. Bogatama Marinusa. Metode penelitian dan analisis data dilakukan dengan beberapa tahapan, yaitu : pengamatan ditempat kerja dan melakukan wawancara mendalam dan pemberian kuisioner kepada para responden pakar yang memiliki pengetahuan tentang pengawasan dan pengendalian mutu produk, penilaian penerapan HACCP dengan metode Self Assessment, perumusan strategi dalam peningkatan sistem pengawasan dan pengendalian mutu melalui pendekatan Analitical Hierarchy Process (AHP).[14]

3. Zainatul Wulandari1, Muh Ugiarto, Ummul Hairah (2017). Zainatul Wulandari1, Muh Ugiarto, Ummul Hairah melakukan penelitian tentang Sistem Informasi Obat-Obatan Herbal. Sistem Informasi ini bertujuan untuk membantu masyarakat dalam mendapatkan informasi mengenai obat-obatan herbal yang berguna untuk membantu menyembuhkan penyakit yang diderita. Sistem informasi ini tidak berisikan informasi mengenai obat-obatan kimia, melainkan hanya berisikan tentang tanaman obat herbal, zat yang terkandung dalam tanaman tersebut, khasiat dan cara pengolahan tanaman tersebut agar dapat digunakan menjadi tanaman obat herbal. Pengembangan sistemnya menggunakan metode Waterfall. Pemodelan analisis dan desain menggunakan bahasa pemrograman PHP dan database server MySQL. Hasil dari penelitian ini adalah sebuah sistem data obat herbal berbasis website yang dapat memudahkan masyarakat dalam pencarian informasi obat herbal dan dapat disimpulkan bahwa sistem dapat di akses oleh user/pengguna.[15]

\section{Metode Penelitian}

Penelitian ini dilakukan di PT Deltomed Laboratories yang beralamat di Dusun Nangger, Nambangan, Selogiri Kabupaten Wonogiri. PT Deltomed Laboratories adalah perusahaan obat herbal dan jamu herbal modern yang berkembang sejak 1976.

Tabel 3.1 Waktu Pelaksanaan Penelitian

\begin{tabular}{|c|c|c|c|c|c|c|c|c|c|c|c|c|c|}
\hline \multirow{3}{*}{ No. } & \multirow{3}{*}{ Nama Kegiatan } & \multicolumn{12}{|c|}{ Waktu } \\
\hline & & \multicolumn{4}{|c|}{ Bulan 1} & \multicolumn{4}{|c|}{ Bulan 2} & \multicolumn{4}{|c|}{ Bulan 1} \\
\hline & & 1 & 2 & 3 & 4 & 1 & 2 & 3 & 4 & 1 & 2 & 3 & 4 \\
\hline 1 & Proposal & $\sqrt{ }$ & & & & & & & & & & & \\
\hline 2 & Pengumpulan Data & & $\sqrt{ }$ & $\sqrt{ }$ & & & & & & & & & \\
\hline 3 & Perencanaan & & & & $\sqrt{ }$ & $\sqrt{ }$ & & & & & & & \\
\hline 4 & Analisis Sistem & & & & & & $\sqrt{ }$ & $\sqrt{ }$ & $\sqrt{ }$ & & & & \\
\hline 5 & Implementasi & & & & & & & & $\sqrt{ }$ & $\sqrt{ }$ & $\sqrt{ }$ & & \\
\hline 6 & Operasi \& Pemeliharaan & & & & & & & & & & & $\sqrt{ }$ & $\sqrt{ }$ \\
\hline 7 & Laporan & & $\sqrt{ }$ & $\sqrt{ }$ & $\sqrt{ }$ & $\sqrt{ }$ & $\sqrt{ }$ & $\sqrt{ }$ & $\sqrt{ }$ & $\sqrt{ }$ & $\sqrt{ }$ & $\sqrt{ }$ & $\sqrt{ }$ \\
\hline
\end{tabular}

Bahan yang digunakan dalam menunjang penelitian ini adalah daftar pedoman urutan kode batch \& koma produk PT Deltomed Laboratories, Data kategori dan hasil pengujian semua produk yang terdaftar di PT Deltomed Laboratories selama satu semester. Adapun peralatan yang digunakan dalam penelitian ini adalah Laptop / CPU, MySQL, Visual Basic, Notepad ++, Star UML. Untuk analisa dan pengumpulan data menggunakan beberapa metode yaitu Studi Kepustakaan, Studi Lapangan (observasi \& wawancara). Tempat yang menjadi objek penelitian adalah : 


\subsection{Rancangan Sistem}

Berdasarkan dari analisis kebutuhan fungsional berikut adalah point - point untuk functional requirements untuk sistem informasi manajemen mutu yang dibuat: Sistem harus dapat melakukan generate laporan berupa rekapitulasi berdasarkan tanggal produk yang di produksi, Sistem bisa menampilkan hasil laporan berupa grafik sesuai dengan hasil kajian yang diinput. Sistem bisa memberikan validasi parameter apa saja yang diinput berupa angka ataupun resume \& kategori apa saja yang bisa dan tidak bisa ditampilkan sebagai laporan. Mengingat banyaknya parameter yang harus diinput dalam proses pengkajian mutu, desain inputan harus dibuat semudah mugkin agar user tidak kesulitan saat melakukan input. Berdasarkan dari analisa functional requirements berikut adalah domain model awal untuk sistem informasi manajemen mutu yang dibuat :

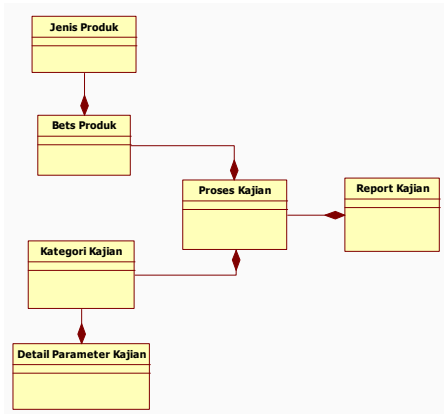

Gambar 3.1 Domain Model Sistem

Pada sistem yang dibuat, berikut adalah desain untuk Use Case Diagram yang terjadi di user :

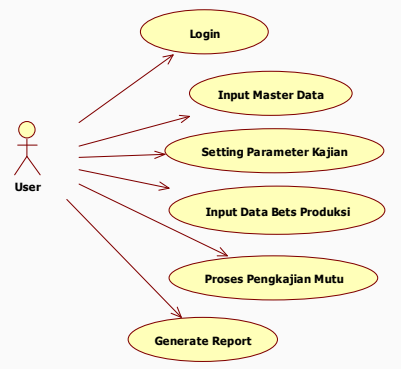

Gambar 3.2 Use Case Diagram User

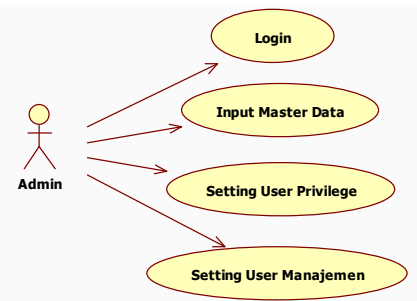

Gambar 3.3 Use Case Diagram Admin

Activity Diagram menggambarkan berbagai aliran aktifitas dalam sistem yang sedang dirancang, bagaimana masing - masing alir berawal, decision yang mungkin terjadi dan bagaimana mereka berakhir. Berikut adalah Activity Diagram yang ditampilkan per proses yang terjadi : 

Vol. 3, No. 2, November 2019, pp. $x x-x x$

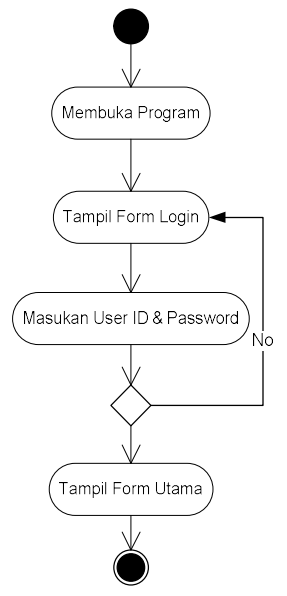

Gambar 3.4 Activity Diagram Login

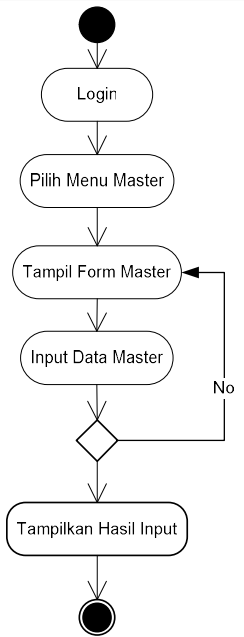

Gambar 3.5 ActivityDiagram Master Data

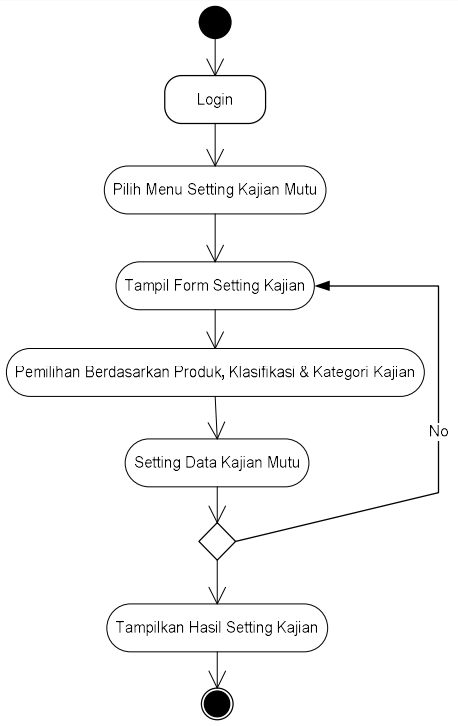

Gambar 3.6 Activity Diagram Setting Kajian Mutu 

Vol. 3, No. 2, November 2019, pp. $x x-x x$

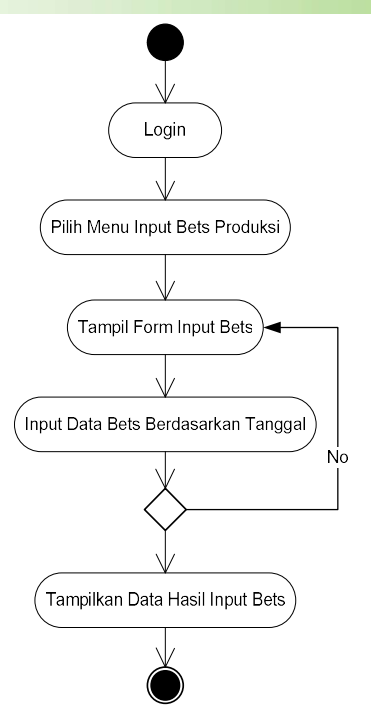

Gambar 3.7 Activity Diagram Input Data Bets

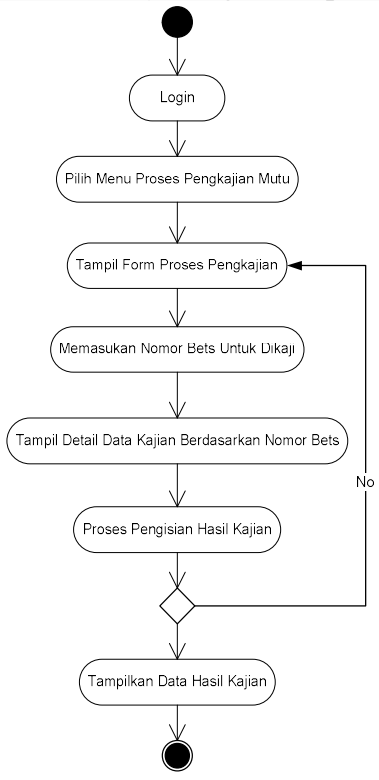

Gambar 3.8 Activity Diagram Proses Kajian Mutu

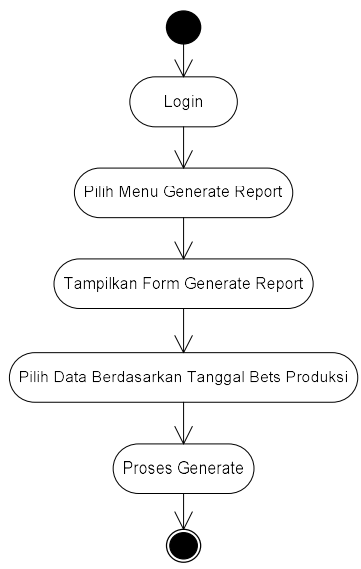

Gambar 3.9 Activity Diagram Proses Kajian Mutu 
Tahapan awal yang dibutuhkan adalah merancang database dan tabel yang akan digunakan. Adapun DBMS yang akan digunakan dalam sistem ini adalah MySQL. Berikut ini adalah struktur database yang digunakan dalam perancangan sistem ini :

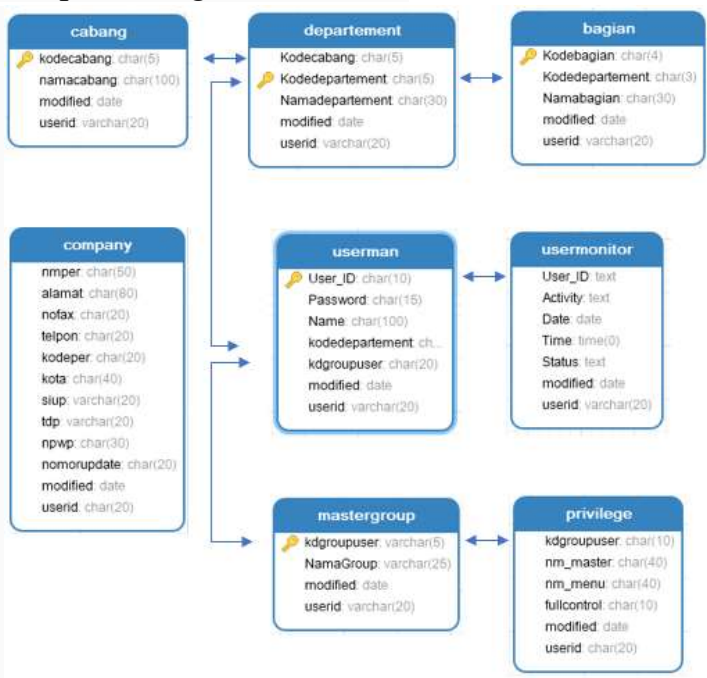

Gambar 3.10 Relasi Database Sistem

Adapun untuk desain menu utama sistem informasi yang akan dibuat adalah sebagai berikut:

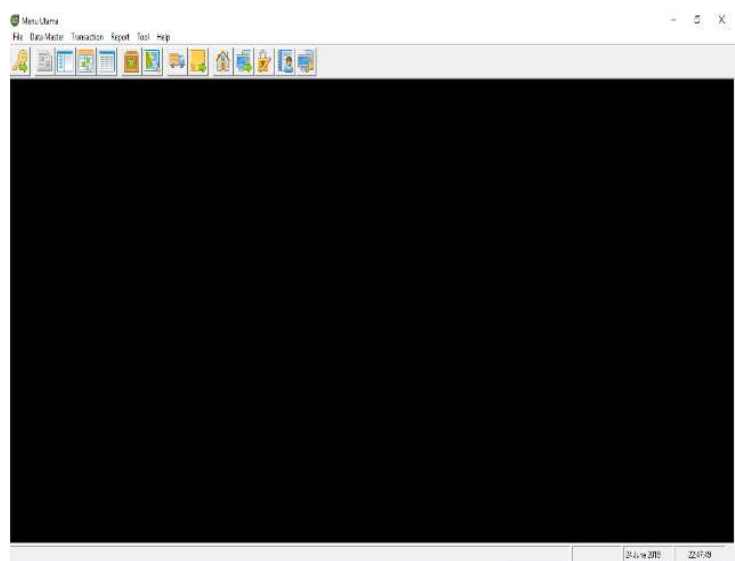

Gambar 3.11 Desain Antar Muka Menu Utama

Berikut adalah desain output report grafik dan rekapitulasi dari system yang dibuat :
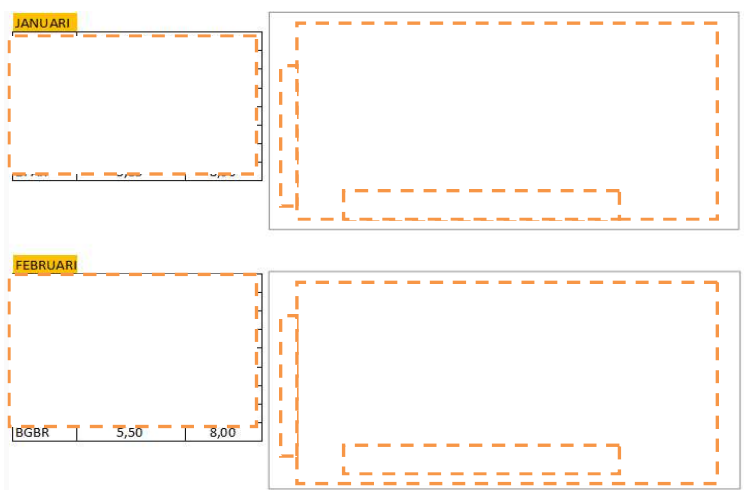

Gambar 3.12 Desain Form Tabel Grafik per Kategori Kajian 


\section{Hasil dan Pembahasan}

Implementasi ini merupakan hasil penerapan sistem yang telah dibangun berdasarkan analisa kebutuhan sampai dengan proses pembuatan sistem informasi yang diusulkan. Pengembangan sistem dilakukan dengan Pemrograman Visual Basic 6 dan database MySQL. Sistem informasi ini dibangun dengan konsep client server \& multi user. Terdapat pemisahan hak akses / privilege untuk masing - masing user. Hal ini dibuat untuk memisahkan wewenang dari tiap department untuk dapat melihat atau mengisi data.

\subsection{Pembahasan}

Untuk tampilan menu dibagi menjadi lima yaitu :

1. File. Menampilkan sub menu yang berisi tools untuk logout user dan exit program

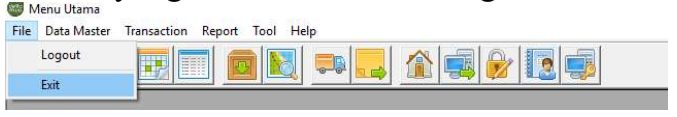

Gambar 4. 1 Tampilan Menu File

2. Data Master. Menu data master menampung sub - sub menu yang digunakan untuk menampilkan form isian yang menyangkut semua data master atau data - data dasar yang harus diisi terlebih dahulu sebagai acuan untuk proses data selanjutnya.

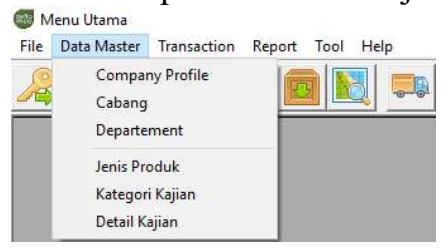

Gambar 4. 2 Tampilan Menu Master

3. Transaction. Menu Transaction berisi sub menu yang berisi form untuk proses transaksi harian. Adapun untuk menunya adalah sebagai berikut :

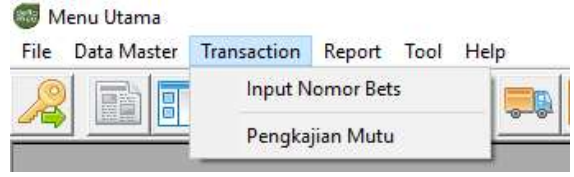

Gambar 4. 3 Tampilan Menu Transaction

4. Report. Menu report mencakup sub menu yang berisi form untuk menampilkan hasil dari inputan pengkajian mutu.

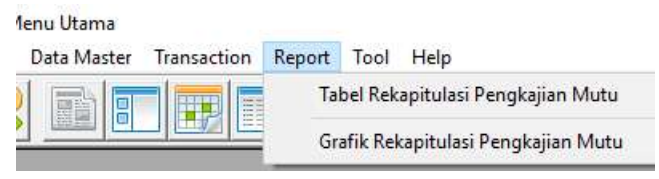

Gambar 4. 4 Tampilan Menu Transaction

5. Tools. Menu tools mencakup form yang berfungsi untuk setting dasar program, seperti seting koneksi, seting user, dll.

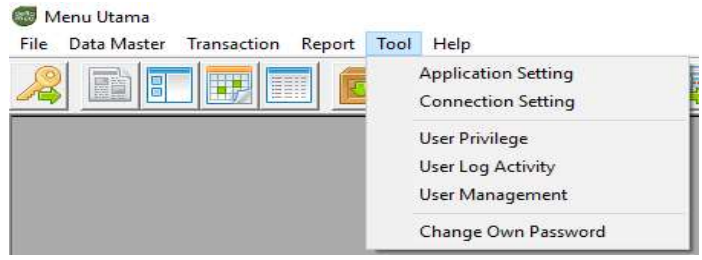

Gambar 4.5 Tampilan Menu Tools 


\subsection{Pembahasan}

Sistem dimulai dari pengisian data master yang semuanya terdapat di menu master. Adapun untuk menu master yang harus diisi adalah sebagai berikut :Company, Cabang, Departement. Untuk modul diatas, nantinya akan digunakan sebagai acuan untuk identitas sistem yang dibuat \& juga sebagai header di semua report yang dihasilkan oleh program. Proses input data tersebut dilakukan oleh bagian IT. Selanjutnya adalah pengisian data jenis produk. Modul ini untuk menyimpan produk apa saja yang di hasilkan oleh PT. Deltomed Laboratories. Bilamana ada perubahan atau penambahan produk bisa langsung ditambahkan melalui modul ini. Proses ini dilakukan oleh bagian administrasi produksi.

Setelah semua jenis produk sudah terisi, langkah selanjutnya adalah pengisian kategori kajian. Semua kategori kajian diinput menjadi satu di modul ini. Sehingga nantinya, jika ada beberapa produk yang menggunakan kategori kajian yang sama tidak perlu melakukan input ulang. Proses ini dilakukan oleh bagian administrasi Quality Assurance.

Proses selanjutnya adalah pengisian data detail kajian mutu. Pada proses inilah pembuatan item - item template kajian mutu per produk dibuat. Setiap proses kajian, dilengkapi dengan validasi untuk inputnya apakah berupa numerik atau bukan. Setiap proses kajian juga dapat diseting apakah nantinya akan ditampilkan di hasil laporan atau tidak. Proses ini juga dilakukan oleh bagian administrasi Quality Assurance. Sampai disini, template untuk kajian mutu sudah selesai dibuat. Sehingga sudah bisa digunakan jika ada produk yang akan di proses untuk kajiannya. Setelah semua setup data master selesai, langkah selanjutnya adalah proses input nomor bets. Nomor bets diinput jika ada proses produksi produk di PT Deltomed Laboratories. Sekali melakukan proses produksi, pada saat itu juga akan dihasilkan nomor bets untuk produk tersebut. Nomor bets dibuat berdasarkan nama produk, tanggal produk tersebut diproduksi dan juga nomor urut.

Berlanjut ke proses inti, selanjutnya adalah proses input hasil kajian mutu produk. Pada proses ini, user memasukan nomor bets yang akan dikaji, maka secara otomatis, semua parameter kajian akan dimunculkan sesuai dengan kriteria pengkajian yang sudah di setup di data master. User hanya tinggal memasukan nilai - nilai hasil kajian yang sudah ditentukan. Sistem akan melakukan validasi input secara otomatis, mana yang seharusnya boleh diinput angka dan mana yang tidak. Selain itu, sistem juga akan melakukan validasi untuk range nilai kajian yang diinput. Sebagai contoh jika ada parameter kajian yang mempunyai range nilai $1 \mathrm{~s} / \mathrm{d} 10$, maka secara otomatis untuk input kajian hanya akan bisa diinput dengan range yang sudah ditentukan tersebut. Desain sistem untuk antarmuka proses kajian dibuat sangat mudah, mengadopsi Ms. Excel untuk tampilan \& perpindahan antar cell sehingga mempercepat proses input kajian mutu yang sedang dilakukan.

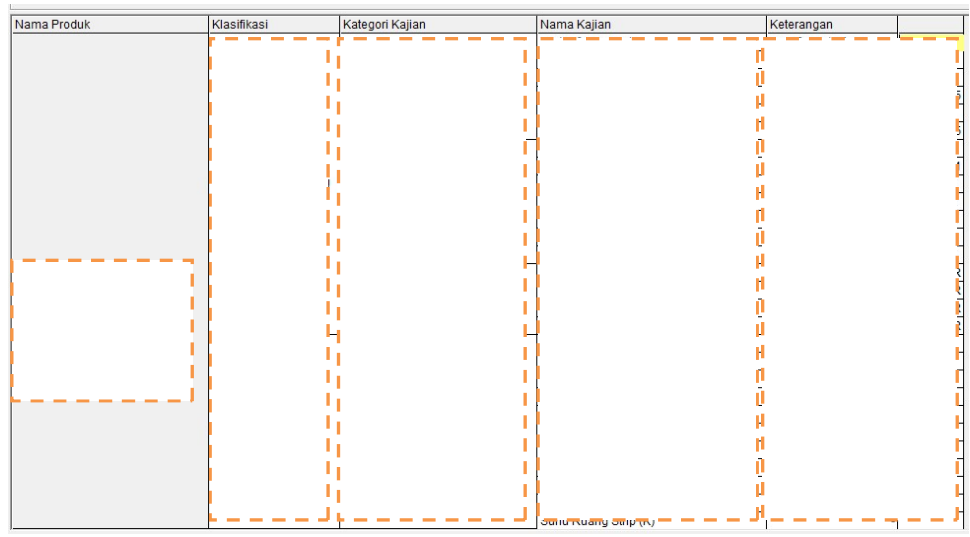

Gambar IV. 26 Tampilan Antar Muka Proses Kajian 
Setelah proses kajian selesai dilakukan, proses terakhir adalah generate report. Report dapat otomatis di generate dari sistem, sesuai dengan data yang sudah diinput sebelumnya. Format report akan disajikan sesuai dengan kaidah yang sudah ditetapkan oleh Badan POM dalam format Excel File. Pengaturan nama sheet, border shell, panjang \& lebar shell, dan lain lain dilakukan otomatis oleh sistem, sehingga user sama sekali tidak perlu melakukan editing dari report yang dihasilkan.

Dari uraian yang dijelaskan diatas, efisiensi \& efektivitas kerja dapat terwujud dengan adanya validasi input, otomatisasi rumus \& template kategori kajian, desain antar muka yang mudah digunakan, serta hasil input yang bisa disajikan dalam bentuk report otomatis tanpa adanya editing sama sekali dari sisi user. Dengan begitu, sistem yang dibuat telah sesuai dengan hasil yang diharapkan.

\section{Kesimpulan}

Dari pembahasan yang telah diuraikan maka dapat disimpulkan hasil penelitian ini sebagai berikut:

- Telah berhasil membuat sistem informasi manajemen mutu produk di PT Deltomed Laboratories.

- Mempermudah manajemen informasi \& administrasi mutu produk, serta menciptakan efisiensi dan efektivitas kerja dalam proses manajemen mutu produk menjadi lebih baik.

Untuk perkembangan sistem ini di kemudian hari maka perlu beberapa saran sebagai berikut :

- Aplikasi pengkajian mutu ini belum terintegrasi dengan program produksi yang berjalan untuk data nomor bets produk. Sehingga kedepan perlu adanya proses integrasi pada modul tersebut agar user tidak perlu lagi melakukan input nomor bet.s.

- Dalam aplikasi pengkajian mutu ini belum tersedia menu untuk kirim email otomatis hasil generate report ke Badan POM. Sehingga diperlukan pengembangan untuk menu tersebut.

\section{Ucapan Terima Kasih}

Atas selesainya penulisan jurnal ini, penulis mengucapkan terima kasih kepada Ibu Donna Setiawati yang telah banyak memberikan bimbingan dan masukan yang sangat membangun.

\section{Daftar Pustaka}

[1] Della Novie Roseta. 2017. Manajemen Mutu Industri Farmasi. Program Studi Profesi Apoteker, Fakultas Farmasi, Universitas Pancasila. Jakarta.

[2] Yusuf, 2019, Manajemen Mutu, https://jurnalmanajemen.com/manajemen-mutu/, Diakses tanggal $19 / 03 / 2019$

[3] Dr. Ridwan Amirudi, SKM., M.Kes, Makalah Pendekatan Mutu dan Kepuasan Pelanggan dalam Pelayanan Kesehatan, 2007 Buku Disarankan untuk Mempelajari Lebih Banyak Tentang Ide ini.

[4] Hudiarto, 2017, Apakah Sistem Informasi Itu?,https://sis.binus.ac.id/2017/09/12/apakah-sisteminformasi-itu-2/, Diakses tanggal 26/03/2019

[5] Agung, Gregorius. (2014). "MySQL untuk Pemula". PT. Elek Media Komputindo Kelompok Gramedia, Jakarta

[6] Haviluddin, Agus Tri Haryono, Dwi Rahmawati. 2016. Aplikasi Program PHP dan MySQL. Mulawarman University Press. ISBN: 978-602-6834-22-5

[7] Pressman, Roger S. 2015. Rekayasa Perangkat Lunak - Buku Satu, Pendekatan Praktisi (Edisi 7). Yogyakarta: Andi.

[8] Al Fatta, H. dan Marco, R., 2015, Analisis Pengembangan dan Perancangan Sistem Informasi Akademik Smart Berbasis Cloud Computing Pada Sekolah Menengah Umum Negeri (SMUN) di Daerah Istimewa 
Yogyakarta, Jurnal Telematika Vol 8 No. 2 Agustus 201563 ISSN : 1979 - 925X e-ISSN : 2442 - 4528, Yogyakarta.

[9] Sugiarti, Yuni. 2015. Analisis dan Perancangan UML (Unified Modelling Language). Yogyakarta: Graha Ilmu

[10] Masruri. 2014. Analisis Efektifitas Program Nasional Pemberdayaan Masyarakat Mandiri Perkotaan (PNPM-MP) (Studi Kasus Pada Kecamatan Bunyu Kabupaten Bulungan tahun 2010). Governance and Public Policy, vol. 1 (1): 53-76

[11]Peraturan Kepala Badan Pengawas Obat Dan Makanan Republik Indonesia Nomor Hk.03.1.33.12.12.8195 Tahun 2012 Tentang Penerapan Pedoman Cara Pembuatan Obat Yang Baik. 2012. Jakarta.

[12] Peraturan Menteri Kesehatan Republik Indonesia Nomor 1799/MENKES/PER/XII/2010 Tentang Industri Farmasi. 2010. Jakarta

[13] Sari, D. P., A. Susanty, \& A. A. Wibowo. 2015. Perancangan Sistem Dokumentasi Mutu Berdasarkan ISO9001:2008 di PT. Degepharm Semarang. Seminar Nasional IENACO. Semarang.

[14] Isnam Junais, Nurdin Brasit Dan Rindam Latief. 2018. Kajian Strategi Pengawasan dan Pengendalian Mutu Produk Ebi Furay PT. Bogatama Marinusa. Teknik Informatika, Fakultas Ilmu Komputer dan Teknologi Informasi, Universitas Mulawarman. Kalimantan Timur.

[15]Zainatul Wulandari1, Muh Ugiarto, Ummul Hairah. 2017. Sistem Informasi Obat-Obatan Herbal. Teknik Informatika, Fakultas Ilmu Komputer dan Teknologi Informasi, Universitas Mulawarman. Kalimantan Timur. 